Wojciech Macek* $^{*}$

\title{
Methodologies of Project Management
}

Submitted: July 22nd 2010.

Accepted: October $7^{\text {th }}, 2010$

\section{Summary}

This paper presents comparison of three most popular project management standards belonging to a wider group of models (for example, PMBOK, Prince 2, CMMI, ISO 10006, BS 6079, IPMA Competence Baseline, European Commission Project Cycle Management Guidelines). The author discusses methods of project management according to PMBoK, Prince 2 and ISO 10006, some chosen criteria and fields of knowledge, such as general regulations of standards, project range management, resources management, and processes connected with risk, systems of project quality management.

\section{Introduction}

PMBoK (Project Management Body of Knowledge) is a set of standards and solutions concerning project management, collected and published by members of PMI (Project Management Institute). The PMBoK Standard is a set of well known and accepted procedures applied in project management. In USA, PMBoK has been approved by American National Standards Institute as national standards of project management.

PRINCE2 (Projects in a Controlled Environment) includes method of project management based on experience of project managers from the Anglo-Saxon countries. It can be applied for management and control of any kinds of projects.

ISO (International Organization for Standarization) is the world federation of national normalization units (member organizations of ISO). The works connected with preparation of international standards are usually done by technical committees of ISO. Each member organization interested in the given field can have their representatives in the suitable committee. International government and other organizations connected with

\footnotetext{
${ }^{*}$ Mgr, doktorant, Politechnika Opolska.
} 
ISO can participate in its works. ISO cooperate with International Electrotechnical Commission (IEC) in all the tasks concerning normalization in electrotechnics.

\section{General regulations of standards}

According to PMBoK assumptions, each project has its defined beginning and end, as well as it has some limited resources at its disposal. There are five basic groups of processes distinguished by PMBoK:

- processes of beginning (definition and approval);

- processes of planning (determination of methods of realization of the assumed aims, resources, sequence etc.);

- processes of realization (grouping and coordination of resources);

- processes of control (monitoring of progress and departures, correcting actions);

- processes of ending (formal acceptation of the final product).

A scheme of the Monitoring \& controlling process groups is presented in figure 1 .

Fig. 1. Monitoring and controlling process group

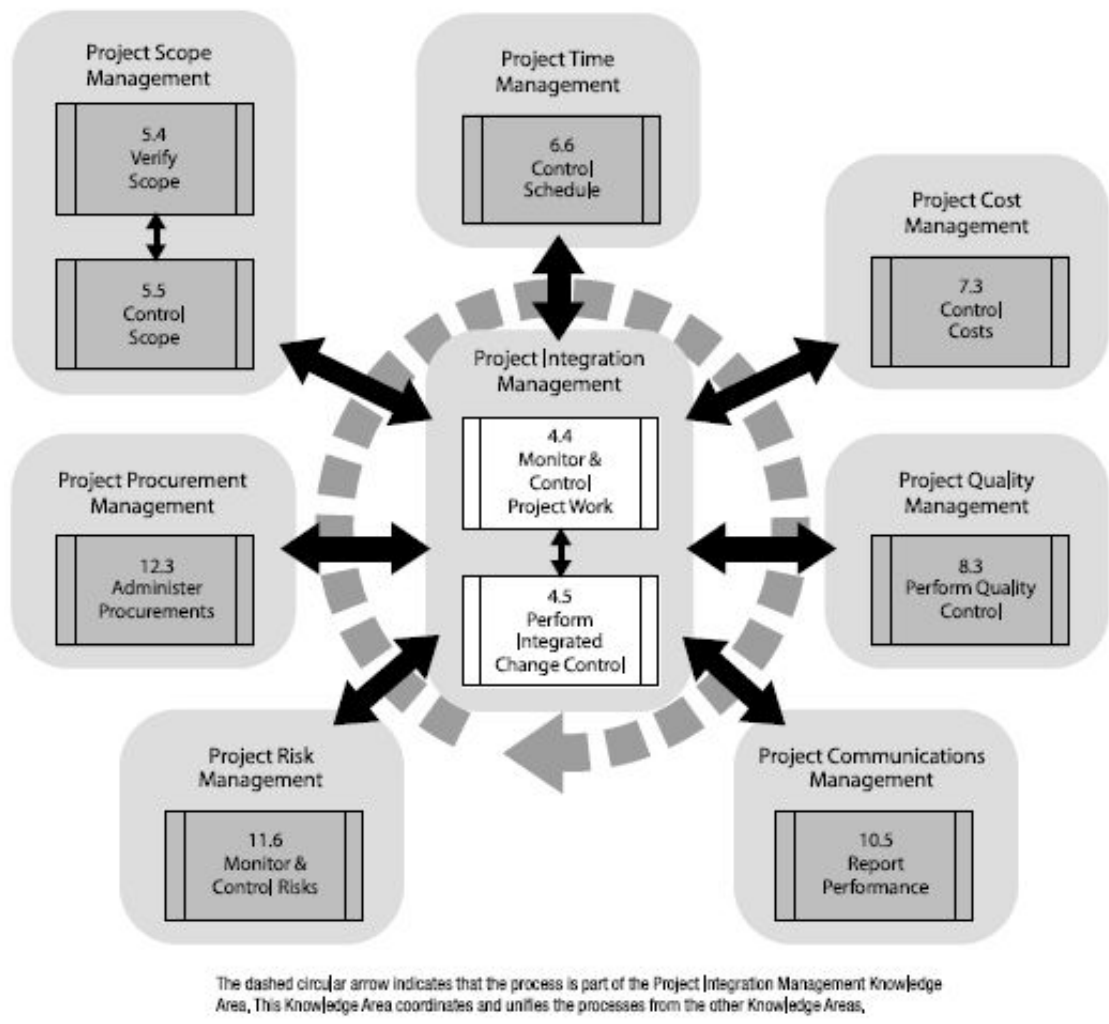

Source: PMBoK Guide, 2008. 
PRINCE2 includes the following project properties:

- the determined and finished duration;

- the defined and measurable business products (results of the project);

- the system of tasks necessary for generation of business products;

- the defined resources;

- the organization structure including duties of the people managing the project.

PRINCE2 assumes the process approach to project management. The eight main processes of the most important order are distinguished; next they are divided into the sub-processes:

- directing a project DP,

- planning PL,

- starting up a project SU,

- initiating a project IP,

- controlling a stage $\mathrm{CS}$,

- managing product delivery MP,

- managing stage boundaries SP,

- closing a project CP.

Table 1 shows the summary model of PRINCE2.

Table 1. Summary model of PRINCE2

\section{ORGANISATION STANDARDS \& APPROACHES; BUSINESS STANDARDS \& ETHICS QUALITY MANAGEMENT SYSTEM (QMS) (ISO9001)}

\begin{tabular}{|c|c|c|}
\hline TECHNIQUES & COMPONENTS & PROCESSES \\
\hline $\begin{array}{l}\text { * Product-Based Planning } \\
\text { - Product Breakdown } \\
\text { - Product Description } \\
\text { - Product Flow Diagram }\end{array}$ & $\begin{array}{l}\text { ^ Organisation } \\
\text { - Structure \& Role Descriptions } \\
\text { ^ Planning } \\
\text { - Products, Activities, Resources }\end{array}$ & $\begin{array}{l}\text { ^ Starting Up A Project (SU) } \\
\text { * Initiating A Project (IP) } \\
\text { ^ Directing A Project (DP) }\end{array}$ \\
\hline $\begin{array}{l}\text { * Quality Reviews } \\
\text { - Preparation, Review, } \\
\text { Follow-up }\end{array}$ & $\begin{array}{l}\text { * Controls } \\
\text { - Management, Team, Quality } \\
\text { * Stages } \\
\text { - Management \& Technical Stages }\end{array}$ & $\begin{array}{l}{ }^{\star} \text { Controlling A Stage }(\mathrm{CS}) \\
\text { ^ Managing Product Delivery (MP) } \\
{ }^{\star} \text { Managing Stage Boundaries (SB) }\end{array}$ \\
\hline $\begin{array}{l}\text { * Change Control } \\
\text { - Capture, Logging, } \\
\text { Assessment, Decision }\end{array}$ & $\begin{array}{l}\text { * Management of Risk } \\
\text { - Risk Assessment \& Management } \\
\text { * Quality in a Project Environment }\end{array}$ & $\begin{array}{l}{ }^{\star} \text { Closing A Project }(\mathrm{CP}) \\
{ }^{\star} \text { Planning }(\mathrm{PL})\end{array}$ \\
\hline $\begin{array}{l}\text { * Project Filing Structure } \\
\text { - Management File } \\
\text { - Specialist File } \\
\text { - Quality File }\end{array}$ & - Quality Requirements \& Response & $\begin{array}{c}\text { THE BUSINESS CASE } \\
{ }^{*} \text { Business Benefits }\end{array}$ \\
\hline $\begin{array}{l}\text { + Existing Organisation } \\
\text { Techniques already used } \\
\text { within the host organisation }\end{array}$ & $\begin{array}{l}{ }^{\star} \text { Change Control } \\
\text { - Capture \& Assessment }\end{array}$ & $\begin{array}{c}\text { RISK MANAGEMENT } \\
\text { * Risk Analysis \& Actions } \\
\text { * Risk Management }\end{array}$ \\
\hline PRII & CE, BEST PRACTICE, CC & $\begin{array}{l}\text { NMENT } \\
\text { NSENSE }\end{array}$ \\
\hline
\end{tabular}

Source: Bradley, 2002. 
The guidelines in the standard ISO 10006 are addressed to many users. They are applied in the case of different projects - big or small, simple or complex, individual or being a part of the program or package of enterprises. The standard includes two application aspects of program management: enterprise processes and enterprise product.

In introduction to the considered standard it is stated that the main general managing group take responsibility for realization of the aims connected with quality, however, people realizing particular stages should be also responsible for quality of all the processes and products.

Generation and keeping up of quality of the process and products require systematic approach. The known and expected requirements of the client and any other sides interested in a given task must be understood and satisfied.

Some phases subjected to management can be distinguished in an enterprise life cycle, such as preparation of the assumptions, the enterprise project, realization and the termination.

\section{The project range management}

According to $\mathrm{PMBoK}$, the project range means a set of works realized within the project. Two groups of works realized within the project can be distinguished:

- processes oriented to the products (for example, determination of requirements, elaboration of the product and its implementation),

- processes of the project management (for example, management of risk, quality, staff).

The range planning concerns description of products and business conditions of the project. Determination of the range management plan is its element. This document should define who can change the previously defined plan, when it is possible and which procedure can be applied in such a case.

In PMBoK, the defined products are the base for determination of WBS (Work Breakdown Structure). At this level, WBS describes the works necessary for production of particular products and intermediate products. WBS has always the hierarchic structure. The first level of WBS includes technological phases of the project, usually resulting from the standard production cycle, and administration works, distinguished as one block of the works. A package (set) of ordered and accepted works is the basic element of WBS necessary for the project manager. Meetings with the future users, introduction of the obtained information into the modeling device, preparation of documents including the process models are the works performed within such a package. Planning at the work level is necessary to managers of technical teams.

Planning of works often includes also a lower level of planning within the process of activity definition. WBS brought to the activity level is the final result of work range planning. It is possible to complete WBS with additional information for specification of the planned works.

In PMI, two processes are used for work management: 
- The project plan realization is an element of the area of management of integrality,

- Verification of the range belongs to the area of range management.

The range change control is used for range management. The range management devices, i.e. procedures of making suitable decisions are the basic part of this process. The reports concerning the work progress are the main base of range changes.

PRINCE2 distinguishes three kinds of works:

- professional works on the product manufacturing;

- administrative works connected with service of contracts, planes, reports etc.;

- works connected with quality management.

During formulation of project control methods, decision rights and procedures of making decisions should be presented. Range management is strongly connected with time and costs planning.

At the stage of initiating a project planning a set of works which have to be done while initiating a project is prepared. Descriptions of works (general for all the project and precise for the initiation phase) are considered and accepted (if necessary) by the project board in the process of project acceptation as elements of greater documents - the draft of the project and plan of the initiation phase. In this moment, acceptation of work plans includes permission for the project initiation given by the project board.

In PRINCE2, realization of works is described from the point of view of the project manager ordering the work package, and the team manager responsible for the work realization. The finished work packages must be accepted by the project manager. The project manager is responsible for checking if the product has been made according to the assumed requirements and standards. The product is included into a set of ready works controlled by the management system.

According to the system ISO 10006, the enterprise targets should include needs and expectations of the client and other sides interested in a given subject. The enterprise targets can be updated while realization. The targets should be included into the enterprise management plan, and we must precisely determine what should be reached (in categories of time, cost and quality of the product) and what should be measured.

It is expected that the specified (minimum) results for previously determined parameters will be delivered.

The projects should have their dates of the beginning and finish as well as the precised limitations concerning costs and resources. They can be long-lasting and they can correct under the influence of internal and external factors.

\section{Resources management}

In PMBoK, HRM (Human Resources Management) includes the processes leading to the more efficient taking advantages of people (clients, sponsors and other participants) in the project. There are many references such as "good practices" concerning - among others - leadership, negotiations, communication, delegations, coaching, mentoring, formation of teams, conflict solutions, enrollment, relations at work, rules concerning safety and health etc. Specific character of such design activities should be taken into account. 
First of all, all the projects are realized by a limited period. A number of participants can be different in particular phases. Participants of a design team rarely manage the human resources but they should know the requirements existing in the project.

Like in many other systems, in PRINCE2 human resources are very important. Appointment of the project manager, i.e. a person responsible for a success of the realized tasks, seems to be the basic element of planning.

Realizing the project, the manager should provide:

- suitable knowledge and resources when and where they are necessary,

- making the project products in a proper time.

Three elements of the project management should be taken into account:

- methods of management,

- organizational structure,

- approach to the solved problems.

Fig. 2. The PROMPT organization structure

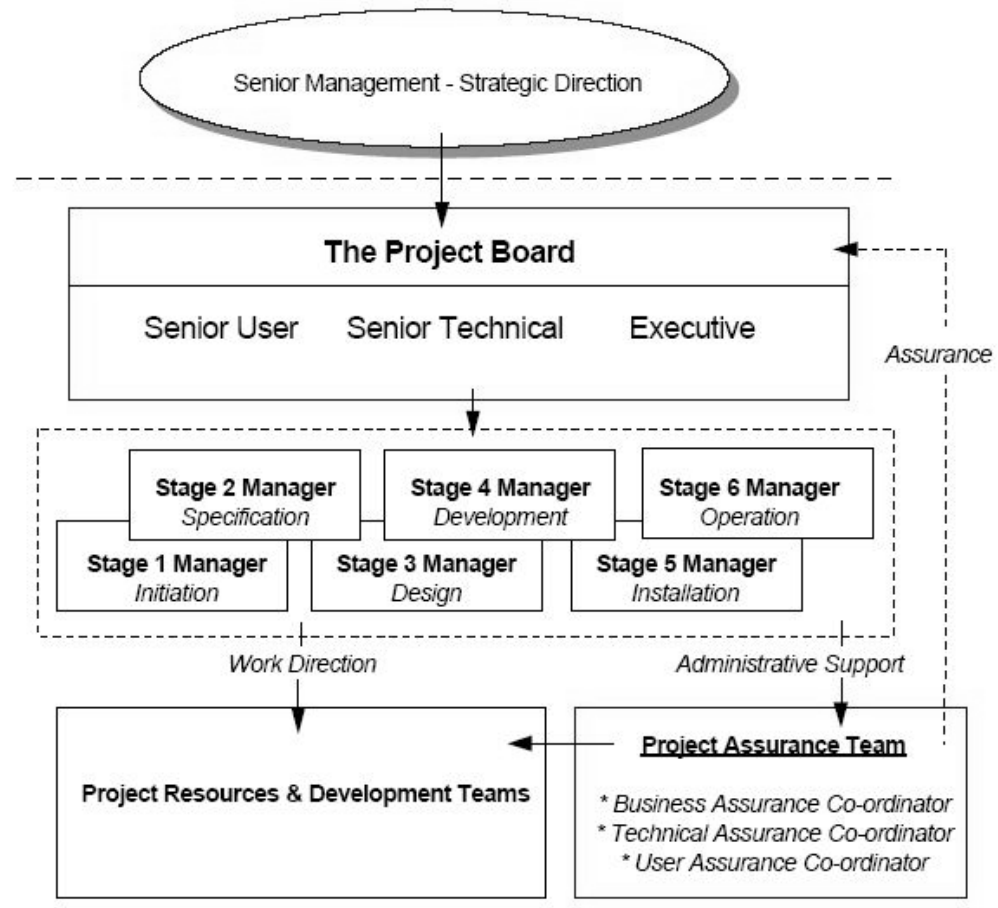

Source: Bradley, 2002.

According to the system ISO 10006, planning and supervision on the resources are the aims of the processes connected with the resources. They are helpful in identification of all the possible problems connected with the resources. The resources include, among others, equipment, devices, finances, information, materials, software, staff, service and site. The processes connected with the resources include: 
- resources planning, and

- supervision of resources.

A resource planning insists in identification of the resources necessary for the enterprise and determination when (at what stage) they are required. The plans should include methods and sources of the finance obtaining, and methods of the finance distribution. If necessary, the plans should also determine methods of disposal of the resource excess.

Importance of the input data for the resources planning should be verified. Assessment of stability, abilities and results of organizations delivering the resources is also recommended.

While planning the resources, it is necessary to take into account any limitations connected with the resources, i.e. accessibility, safety, traditions, international agreements, trade unions agreements, national regulations, funds, influence of the enterprise on the environment.

It is recommended to evidence the resource plans concerning estimations, assignments, limitations, and introduce them to the enterprise management plan together with the given assumptions.

In the case of the resources supervision it is recommended to realize inspections of the given data in the fixed terms. Such inspections help to provide the resources necessary to realization of the enterprise aims. Deviations from the resources plans should be identified, analyzed; next suitable actions must be undertaken and registered.

Any decisions concerning the realized tasks should be made after consideration of influence of those tasks on other processes of the enterprise and its aims. The changes influencing the enterprise aims should be discussed with the client and the other interested sides. The enterprise quality and success are strongly depended on the staff. Thus, any actions in the processes connected with the staff are especially important. Generation of the environment where the staff can efficiently realize the planned tasks is the main purpose of these processes.

The processes concerning the staff include:

- formation of the organizational structure of the enterprise,

- assignment of the staff to particular tasks, and

- formation of the teams.

Organizational structure of the enterprise should be prepared according to requirements of the organization initiating the enterprise and the assumed special conditions. If possible, the accessible experiences from the previous enterprises could be taken into account for selection of the best organizational structure.

It is necessary to identify and establish connections between the organization realizing the enterprise and:

- the client and other engaged sides,

- the functions assisting in the organization initiating the enterprise (especially those engaged in monitoring schedules, quality, costs etc.),

- other suitable enterprises in the organization initiating the considered enterprise.

According to ISO 10006, all the members of the team should participate in the processes connected with the team forming and improvement of the obtained results. All 
the members must be subjected to training and they should be conscious of importance of their actions and the enterprise aims.

\section{Processes connected with risk}

In PMI, the risk management is an isolated group of processes. The problem of risk occurs in the field of time management, cost management, provision management, communication management and integrality management.

According to PMI, there is a possibility of risk service by the team outside the project, responsible only for the risk management.

The plan of risk management should describe methods of risk searching, for example the method of application of the external sources (lists of risks), people engaged in identification and analysis of risk.

All the processes and activities connected with risk are the cost sources, because they need some resources. According to PMI, it is necessary to evidence, report and audit all the processes connected with risk management.

In the risk management area, PRINCE2 concentrates on the processes including the risk service, organizational relations and methods of risk evidence. PRINCE2 does not include a process leading to formulation of strategy of risk management in the project. It means that each risk must be separately considered. There is no separate budget for risk

Fig. 3. Example of risk breakdown structure RBS

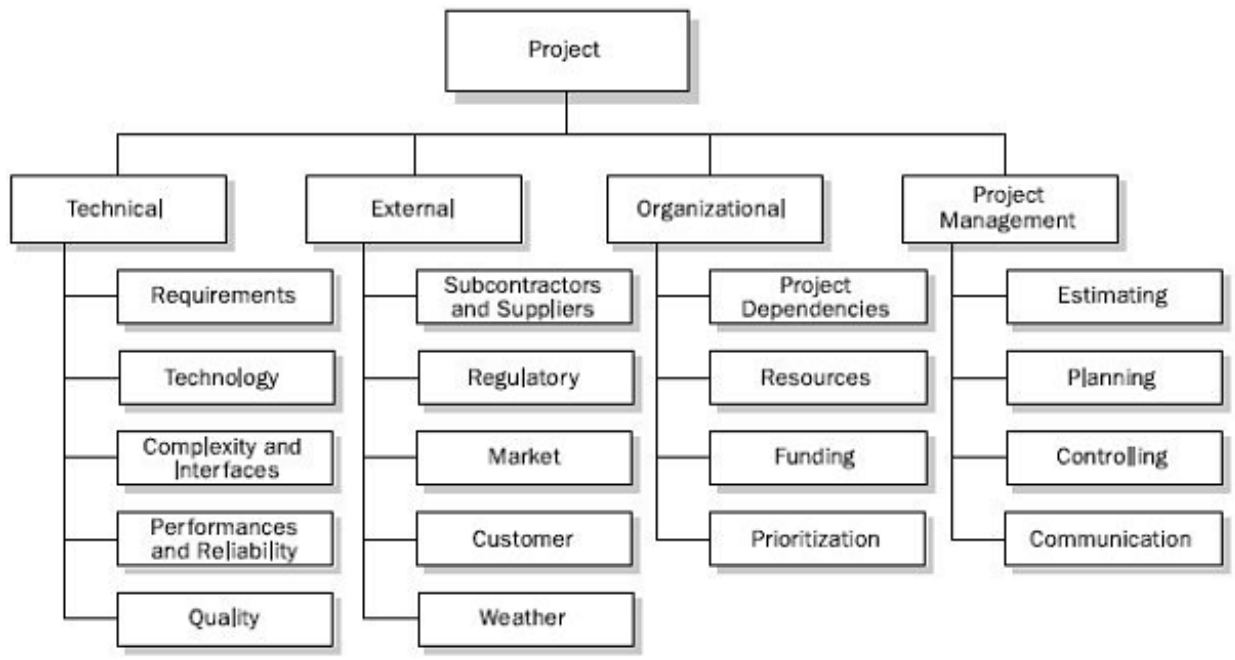

The Risk Breakdown Structure (RBS) lists the categories and sub-categories within which risks may arise for a typical project, Different RBSs will be appropriate for different types of projects and different types of organizations, One benefit of this approach is to remind participants in a risk identification exercise of the many sources from which project risk may arise,

Source: PMBoK Guide, 2008. 
management, it is not possible to separate risk management for an external team competences.

Standard ISO 10006 requires a structural approach and its evidence in the risk management plan is recommended. The aim of processes connected with risk is minimize influence of possible undesirable events and making full use of improvement possibilities.

Uncertainty concerns both the enterprise processes and the product. There are the following processes connected with risk:

- identification of risk,

- assessment of risk,

- procedures connected with risk,

- risk control.

Risk should be identified at the stage of the enterprise initiation, while evaluation of progress, or while making important decisions. In such a case, the experience or the data from previous enterprisers should be used. This process output should be written down in the risk management plane, and the risk management plane must be included into the enterprise management plane. Interaction between different risks should be taken into account, and risk connected with introduction of new technologies must be identified.

The process of risk assessment includes analysis and determination of the identified risk connected with the processes and products of the enterprise. Standard ISO10006 recommends assessment of all the identified risks.

The solutions leading to elimination, decrease, transfer, division or acceptation of risk and plans of applications of possibilities should be based on the known techniques or data coming from the people experiences. The accepted risks should be identified and evidenced.

Special attention should be paid to solutions connected with the prospective risks occurring in interactions between actions, processes, and products and the organization realizing the enterprise, the initiating organization and other engaged sides.

\section{Systems of project quality management}

PMI used the definition of quality taken from the Standard 8402. According to that definition, quality includes all the characteristics connected with meeting any needs by the product or service. The basic problem is transformation of assumptive needs into requirements what is performed in the area of range management.

As for quality management, PMI uses the ISO standards. Quality management includes the processes necessary for providing that the project will satisfy the assumed needs. According to the standard ISO 8402, the processes include all the general management functions determining quality policy, aims and responsibilities, and implementing them by means such as quality planning, quality assurance, quality control and quality improvement within the quality system.

Quality planning is determination of the quality standards obligatory in the project and the methods of their reaching. The base of quality planning is general quality policy of the firm, i.e. general approach to the problems connected with quality expressed by the firm management. Such policy must be always adapted to the real project. Adaptation of quality 
policy to the real project is influenced by the project range, description of product, and standards and regulations adequate to the project range. Regulations should be understood as strict legal standards etc. Standards are the instructions determining the work methods and properties of the product. While quality planning, it is necessary to remember about planning in other fields, for example procurement planning (the firm delivering intermediate products for our project can have their own quality system).

PMI suggests application of graphical techniques for quality planning, for example the Ishikawa diagrams or block diagrams. The suggested techniques can help in understanding the process nature and determination of the suitable approach. Such techniques can be helpful in all the fields of management. However, we are able to understand the project nature without a graphical presentation. The "experiments" can be used for quality planning.

The plan of quality management should be a result of quality planning. In PMI, they say that such plan should describe organizational structures, responsibilities, procedures, processes and resources necessary for quality management implementation.

Quality assurance includes activities leading to providing all the necessary quality standards by the project.

In the projects, quality assurance is usually realized by an external department of quality assurance, independent from the project. However, this process can be realized by a special team working within the project, or by a client for which the project is addressed. In such a case, the quality audits are the basic technique. The quality audits insist in regular inspections of the activities connected with quality management, and search of any possible non-conformities with the assumed standards are their aim.

In PMI, the quality control process is engaged in check of conformity of technical products and intermediate products, and the management work results with the assumed standards. A level of the budget use or conformity with the assumed schedule can be applied as measures of management quality. Inspection is the basic technique of quality control.

The quality plan should include improvement of the project processes.

PRINCE2 uses two definitions of quality:

- product quality - usability of the product for the assumed purposes,

- process quality - possibility of product delivery in the way involving no problems.

The project should be realized according to the quality standards, so it is necessary to comprimise on quality assurance systems valid in the firm realizing the project and at the client's place.

The quality plan is a result of quality planning - it can be introduced into the project plan. Moreover, the quality register is formed. It describes all the activities connected with quality checking.

According to PRINCE2, the project board is responsible for quality assurance. The people from the project assurance team can participate in realization of tasks connected with quality assurance. The people are responsible for application of technical standards and quality standards. They are especially responsible for realization of quality control processes determined in the project quality plan and audits independent on the project manager. However, PRINCE2 does not include the process taking those processes into account. 
Fig. 5. Project quality

\section{Project Quality}

Management Overview

\subsection{Plan Quality}

.1 Inputs

1 Scope baseline

2 Stakeholder register

.3 Cost performance baseline

.4 Schedule baseline

5 Risk register

.6 Enterprise environmental

factors

.7 Organizational process assets

.2 Tools \& Techniques

, 1 Cost-benefit analysis

, 2 Cost of quality

3 Control charts

.4 Benchmarking

5 Design of experiments

, 6 Statistical sampling

,7 Flowcharting

8 Proprietary quality management methodologies

.9 Additional quality planning tools

.3 Outputs

1 Quality management plan

.2 Quality metrics

3 Quality checklists

.4 Process improvement plan

.5 Project document updates

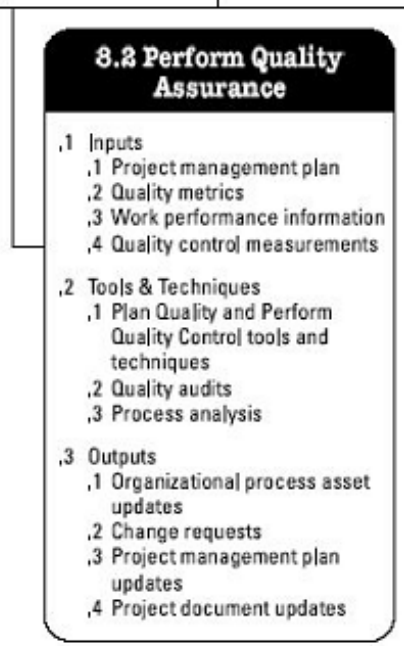

Source: PMBoK Guide, 2008.

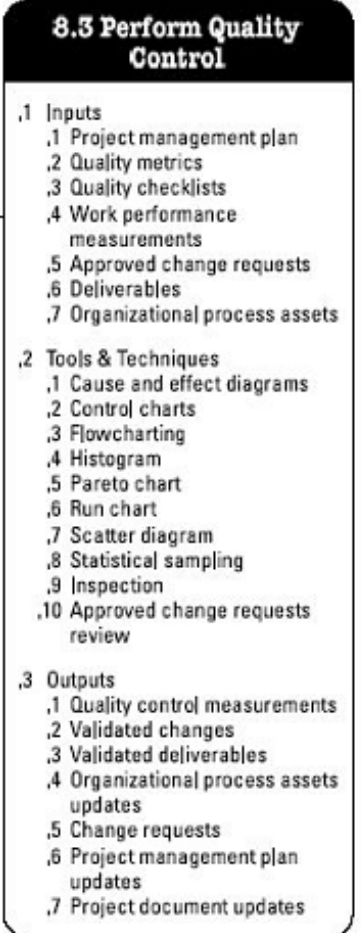

The quality review includes three stages:

- preparation,

- meeting,

- the succesive actions.

At the preparation stage, the assigned people obtain the product for a review. The meeting insists in discussion about all the errors or mistakes. The participants of the meeting should talk as partners.

Any corrections of the project product are the result of quality review. The manager of the technical team generating a product is responsible for those works. The end of the actions defined during the review must be reported and signed by a suitable person. If necessary, the product must be subjected to quality review once again..

According to ISO 10006, the rules of quality management include:

- orientation of the client,

- leadership,

- engagement of people, 
- process approach,

- system approach to management,

- continuous training;

- making decisions based on the facts,

- advantageous connections with suppliers.

These general rules should be the base of the quality management systems in organizations initiating and realizing enterprises.

Management of the enterprise processes within the quality management system is necessary for the enterprise aim obtaining. The quality management system should be as coherent as possible with the quality management system valid in the organization initiating the enterprise.

The necessary documents generated by the organization realizing the enterprise should be defined and controlled in order to provide efficient planning, implementation and supervision of the enterprise.

According to Standard ISO10006, the quality management system should be evidenced and included into the enterprise quality plan, or formed within it.

In the case of contracts, the client can determine the requirements concerning the quality plan. The requirements should not limit the quality plan range applied by the realizing organization.

\section{Application of informatics devices for project management}

Different programming devices, with various advantages levels, are usually applied during work planning. There are many programs for project management, helping in work management and human resources.

So-called PPMs (Project Portfolio Management) belong to the advanced devices applied for management and optimization of investments. Devices of that type are usually implemented in the firms where project realization or support of operation activities by projects is the base of their performance. PPMs allow monitoring and analyzing efficiency of all the realized projects and their budgets.

Software of that type is represented by, for example PPM Open Projects, HP Project $\&$ Portfolio Management Services, IBM Rational ${ }^{\circledR}$ project management.

Microsoft Project belongs to the most popular programs for project management. It helps in management of projects, resources, time and finances of the project. This device offers good reporting devices, developed interfaces for management of important aspects of the project. MS Project is fully integrated with other elements of Microsoft Office.

PRINCE2 methodology, in partnership with IBM (UK) have developed a support tool called "The PRINCE2 Environment". This tool provides a complete electronic support function which enables the Project Manager (or Project Support) to keep track of the many project documents that are created during the life of the project and to launch any application that is needed to manage the project.

Typical applications will be project planning tools, word-processing and spreadsheets; both applications and associated files can be launched, modified and saved. The PRINCE2 
Environment also contains the full PRINCE documentation and "skeletons" for the creation of the Project Initiation Document. Users can add extra options and incorporate their existing documentation to supplement the basic material supplied with the PRINCE2 Environment. An alternative - The Launch Pad - is available from SPOCE Project Management Limited, providing similar functionality to the PRINCE2 Environment.

\section{Conclusions}

From time to time people, who want to understand this knowledge area, are asked to recommend project management systems and methodologies, or to compare them as part of some selection process. Indeed, three compared methodology really serve different purposes and are therefore not directly comparable.

Presented manuals are very general, as such does not cover the situation of multiple prime contracts. In such cases, the issues of work coordination responsibility are much more complex.

Fig. 6. Process groups interact from PMBoK

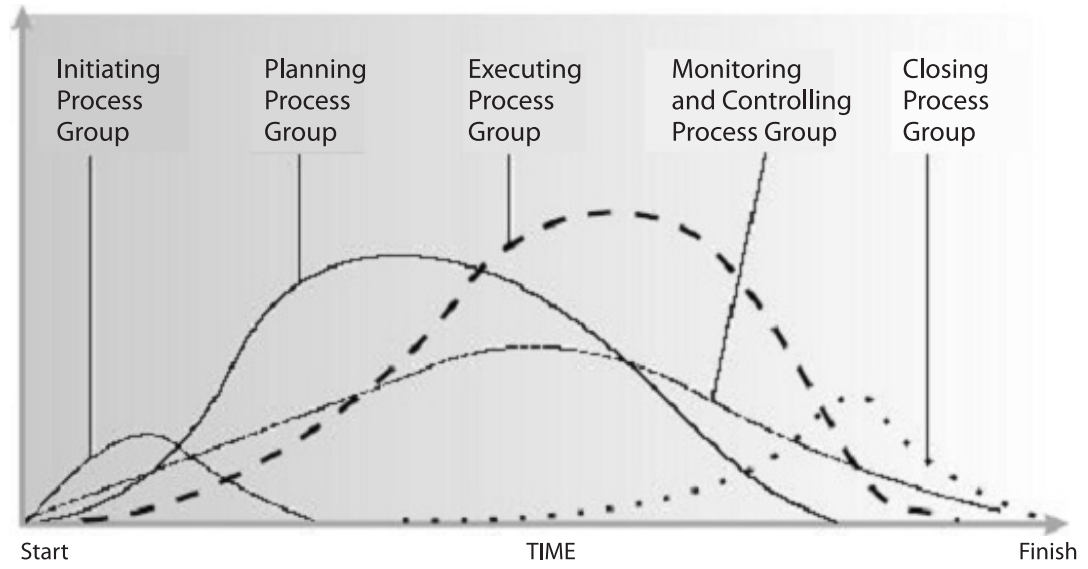

Source: PMBoK Guide, 2008.

\section{References}

Bradley K., Understanding PRINCE 2, 2002.

ISO 10006: 2003, Quality management systems- Guidelines for quality management in projects, 2003. PMBoK Guide, An American National Standard ANSI/PMI 99-001-2008, Project Management Institute, IV ed., 2008.

PN- ISO 8402: 1996, Zarzq̨dzanie jakościq i zapewnienie jakości. Terminologia. 


\section{Metodologia zarządzania projektami}

\section{Streszczenie}

W niniejszej pracy przedstawiono charakterystykę porównawcza trzech najbardziej popularnych obecnie standardów zarzqdzania spośród szerszej grupy modeli (np. PMBOK, PRINCE2, CMMI, ISO 10006, BS 6079, IPMA Competence Baseline, European Commission Project Cycle Management Guidelines). Artykut przedstawia metodologie zarzadzania projektami wg PMBOK, PRINCE2 oraz ISO 10006 w oparciu o wybrane kryteria i obszary wiedzy takie, jak.: Postanowienia ogólne standardów; Zarzqdzanie zakresem projektu; Zarzadzanie zasobami; Procesy dotyczace ryzyka; oraz Systemy zarzqdzania jakościa projektów. 